\title{
Task 3.10 - Gas Separation and Hot-Gas Cleanup
}

\section{Topical Report \\ August 1995}

By

Michael L. Swanson
RECEIVED

AUG 151997

OSTI

Work Performed Under Contract No.: DE-FC21-93MC30097

For

U.S. Department of Energy

Office of Fossil Energy

25

- Federal Energy Technology Center

Morgantown Site

P.O. Box 880

$\frac{\infty}{\infty}$

Morgantown, West Virginia 26507-0880

By

Energy \& Environmental Research Center

University of North Dakota

P. O. Box 9018

Grand Forks, North Dakota 58202-9018

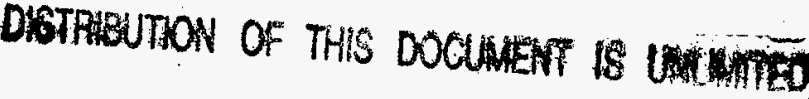

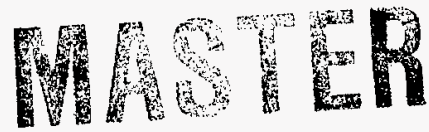




\section{Disclaimer}

This report was prepared as an account of work sponsored by an agency of the United States Government. Neither the United States Government nor any agency thereof, nor any of their employees, makes any warranty, express or implied, or assumes any legal liability or responsibility for the accuracy, completeness, or usefulness of any information, apparatus, product, or process disclosed, or represents that its use would not infringe privately owned rights. Reference herein to any specific commercial product, process, or service by trade name, trademark, manufacturer, or otherwise does not necessarily constitute or imply its endorsement, recommendation, or favoring by the United States Government or any agency thereof. The views and opinions of authors expressed herein do not necessarily state or reflect those of the United States Government or any agency thereof. 


\section{DISCLAIMER}

This report was prepared as an account of work sponsored by an agency of the United States Government. Neither the United States Government, nor any agency thereof, nor any of their employees makes any warranty, express or implied, or assumes any legal liability or responsibility for the accuracy, completeness, or usefulness of any information, apparatus, product, or process disclosed or represents that its use would not infringe privately owned rights. Reference herein to any specific commercial product, process, or service by trade name, trademark, manufacturer, or otherwise does not necessarily constitute or imply its endorsement, recommendation, or favoring by the United States Government or any agency thereof. The views and opinions of authors expressed herein do not necessarily state or reflect those of the United States Government or any agency thereof.

\section{ACKNOWLEDGMENT}

This semiannual was prepared with the support of the U.S. Department of Energy (DOE) Morgantown Energy Technology Center Cooperative Agreement No. DE-FC21-93MC30097. However; any opinions, findings, conclusions, or recommendations expressed herein are those of the author(s) and do not necessarily reflect the views of the DOE.

\section{EERC DISCLAIMER}

LEGAL NOTICE This research report was prepared by the Energy \& Environmental Research Center (EERC), an agency of the University of North Dakota, as an account of work sponsored by U.S. Department of Energy. Because of the research nature of the work performed, neither the EERC nor any of its employees makes any warranty, express or implied, or assumes any legal liability or responsibility for the accuracy, completeness, or usefulness of any information, apparatus, product, or process disclosed, or represents that its use would not infringe privately owned rights. Reference herein to any specific commercial product, process, or service by trade, trademark, manufacturer, or otherwise does not necessarily constitute or imply its endorsement or recommendation by the EERC. 


\section{TABLE OF CONTENTS}

LIST OF FIGURES $\ldots \ldots \ldots \ldots \ldots \ldots \ldots \ldots \ldots \ldots \ldots \ldots \ldots \ldots \ldots \ldots$

LIST OF TABLES $\ldots \ldots \ldots \ldots \ldots \ldots \ldots \ldots \ldots \ldots \ldots \ldots \ldots \ldots \ldots$

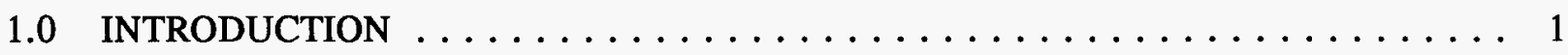

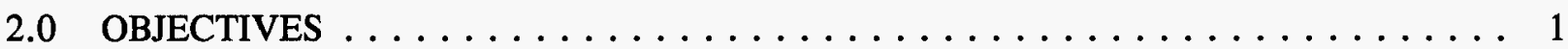

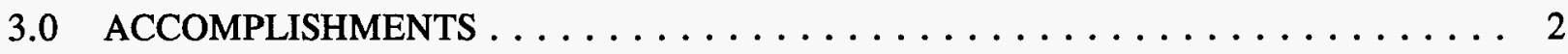

3.1 Equipment Description and Operating Procedures . . . . . . . . . . . 2

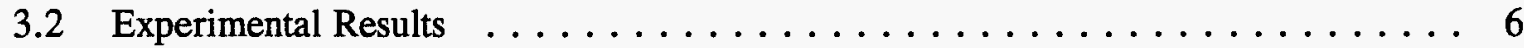

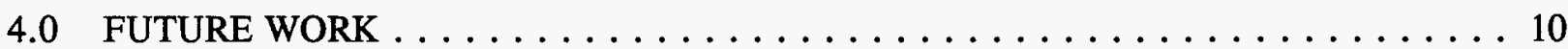

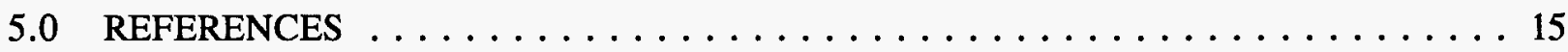




\section{LIST OF FIGURES}

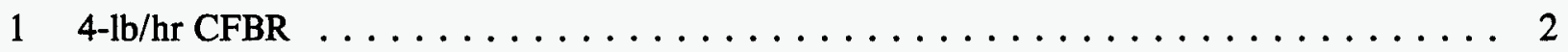

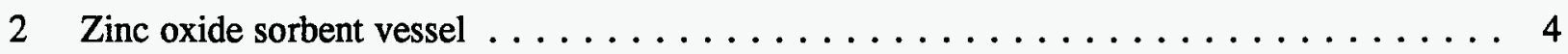

3 Piping modifications on the $4-\mathrm{lb} / \mathrm{hr}$ CFBR $\ldots \ldots \ldots \ldots \ldots \ldots \ldots \ldots \ldots$

4 Permeate flow rate versus run time for Membrane 1 tested at various conditions

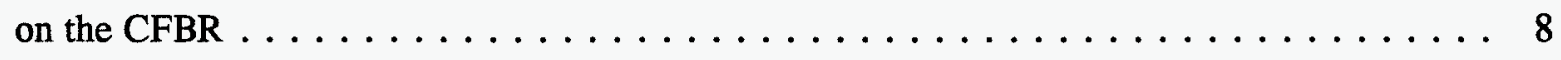

5 Permeate flow rate versus run time for Membrane 2 tested at various conditions

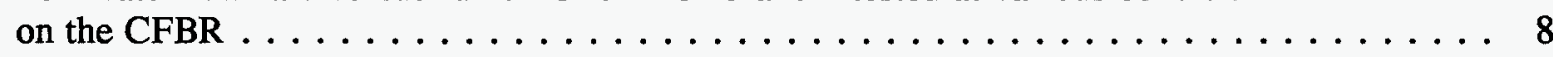

6 Permeate flow rate versus run time for Membrane 3 tested at various conditions

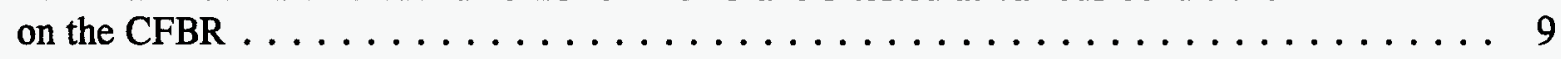

7 Comparison of $\mathrm{H}_{2}$ permeability for bottled gas and coal gas tests in the CFBR using Pd-Ag

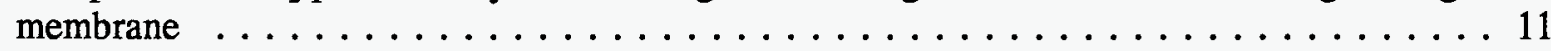

$8 \quad \mathrm{H}_{2}$ permeability for bottled gas and coal gas tests in the the CFBR using palladium membrane as compared to $\mathrm{Pd}-\mathrm{Ag}$ membrane baseline . . . . . . . . . . . . 11

9 ESCA analysis of Pd-Ag membrane with deposited layer on the feed gas side of the

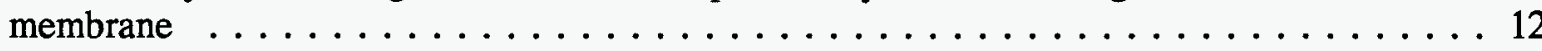

10 Detailed ESCA analysis of Pd-Ag membrane identifying deposited layer as

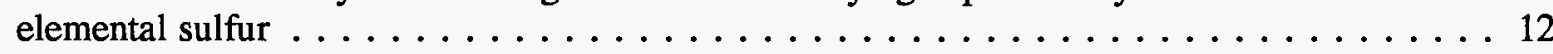

\section{LIST OF TABLES}

1 Proximate and Ultimate Analyses of Wyodak Subbituminous Coal from the Powder River Basin Mixed with $\mathrm{CaCO}_{3} \ldots \ldots \ldots \ldots \ldots \ldots \ldots \ldots$

2 Operating Conditions from Product Gas Tests on Pd-Ag Membrane $\ldots \ldots \ldots \ldots \ldots$

3 Operating Conditions from Product Gas Tests Using Palladium Membrane $\ldots \ldots \ldots \ldots 7$

4 Gas Chromatograph Data from Bottled Gas Tests on Pd-Ag Membrane Including Corrected Data from Permeate Gas Stream . . . . . . . . . . . . . . 13

5 Gas Chromatograph Data from Bottled Gas and Coal Gas Tests on Pd-Ag Membrane Including Corrected Data from Permeate Gas Stream $\ldots \ldots \ldots \ldots \ldots \ldots$

6 Gas Chromatograph Data from Bottled Gas and Coal Gas Tests on Palladium Membrane . . 14

7 Separation Factors and Permeabilities of Corrected Permeate Gases Through Pd-Ag Membranes . . . . . . . . . . . . . . . . . . . . . . 14 


\section{TASK 3.10 GAS SEPARATION AND HOT-GAS CLEANUP}

\subsection{INTRODUCTION}

Catalytic gasification of coal to produce $\mathrm{H}_{2}-, \mathrm{CO}$-, and $\mathrm{CH}_{4}$-rich mixtures of gases for consumption in molten carbonate fuel cells is currently under development; however, to optimize the fuel cell performance and extend its operating life, it is desired to separate as much of the inert components (i.e., $\mathrm{CO}_{2}$ and $\mathrm{N}_{2}$ ) and impurities (i.e., $\mathrm{H}_{2} \mathrm{~S}$ and $\mathrm{NH}_{3}$ ) as possible from the fuel gas before it enters the fuel cell. In addition, the economics of the integrated gasification combined cycle (IGCC) can be improved by separating as much of the hydrogen as possible from the fuel, since hydrogen is a high-value product. Researchers at the Energy \& Environmental Research Center (EERC) and Bend Research, Inc., investigated pressure-driven membranes as a method for accomplishing this gas separation and hot-gas cleanup. These membranes are operated at temperatures as high as $800^{\circ} \mathrm{C}$ and at pressures up to $300 \mathrm{psig}$. They have very small pore sizes that separate the undesirable gases by operating in the Knudsen diffusion region of mass transport (30-50 $\AA$ ) or in the molecular sieving region of mass transport phenomena $(<5 \AA)$. In addition, $\mathrm{H}_{2}$ separation through a palladium metal membrane proceeds via a solution-diffusion mechanism for atomic hydrogen. This allows the membranes to exhibit extremely high selectivity for hydrogen separation.

Technological and economic barriers to be resolved before these membranes are commercially viable include improved gas separation efficiency, membrane optimization, sealing of membranes to metal vessels, high burst strength of the membrane, pore thermal stability, and material chemical stability. Hydrogen separation is dependent on the temperature, pressure, pressure ratio across the membrane, and surface area of the membrane. For gas separation under Knudsen diffusion, increasing feed pressure and pressure ratio across the membrane should increase the gas permeability, while decreasing the temperature and decreasing the permeate-to-total flow ratio should also increase the gas permeability. In the molecular sieving regime of mass transport, the inlet pressure and pressure ratio should have no effect on gas permeability, while increasing temperature should increase permeability.

\subsection{OBJECTIVES}

The selectivity of the ceramic membranes for removing undesirable gases while allowing the desired gases to be concentrated in the permeate stream was to be determined. Specific questions to be answered included:

- What are the effects of membrane properties (i.e., surface area, pore size, and coating thickness) on permeability and selectivity of the desired gases?

- What are the effects of operating conditions (i.e., temperature, pressure, and flow rate) on permeability and selectivity?

- What are the effects of impurities (i.e., small particulate, $\mathrm{H}_{2} \mathrm{~S}, \mathrm{HCl}, \mathrm{NH}_{3}$, etc.) on membrane performance? 


\subsection{ACCOMPLISHMENTS}

\subsection{Equipment Description and Operating Procedures}

The most cost-effective way to perform the desired tests on the membrane was to conduct both the baseline separation efficiency tests using bottled gas and the impurity degradation tests using actual coal-derived fuel gas in the same equipment. Originally, it was proposed to build a separate test stand to conduct the separation efficiency tests using bottled gases. However, it was decided that this method would waste too many valuable resources duplicating similar capabilities. Modification of the EERC's continuous fluid-bed reactor (CFBR) represented the most cost-effective alternative.

Figure 1 shows the 4-lb/hr CFBR used for gasification tests with various coals. The unit was originally designed as a pyrolysis unit for a U.S. Department of Energy (DOE) mild gasification program, but it has been used since for gasification, pyrolysis, and combustion on a variety of projects. Although predominantly operated as a fluid bed, the unit has been operated as a fixed bed by using lower gas flow rates or larger particle sizes in the bed. The unit was intentionally designed to be flexible.

Gas used for fluidization is mixed in a gas manifold. Bottled gas, house nitrogen, house air, and any liquid desired (such as steam) are first preheated, then mixed, and heated to reaction temperature in a superheater ( $20 \mathrm{ft}$ of $3 / 8$-in. tubing coiled into an 18 -in. ceramic fiber heater). Two bottled gases in combination with either house air or house nitrogen and a liquid can be used at the present time. Using more bottled gases in the feed gas mix would involve additional mass flow controllers.

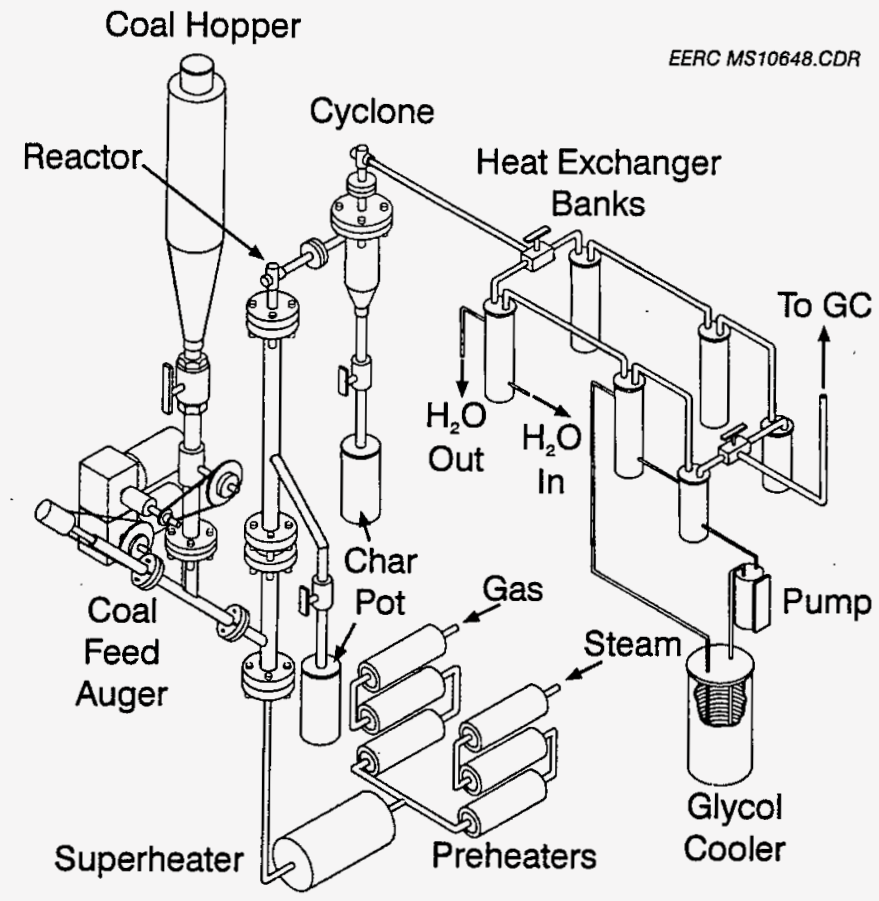

Figure 1. 4-lb/hr CFBR. 
The reactor was constructed of $316 \mathrm{H}$ stainless steel Schedule 80 pipe. The first (bottom) section is made of 3-in. pipe and is 33 in. in length. The next (top) reactor section is made of 4-in. pipe, $18.75 \mathrm{in}$. in length. The two sections are connected with a $316 \mathrm{H}$ weld reducer. The unit was designed such that the top of the fluid bed lies 33 in. above the coal injection point. A solids offtake leg at the top of the bed is the primary means of solids removal from the reactor. A ball valve facilitates the collection of product while the system is operating.

The reactor has two ceramic fiber heaters to maintain the vessel's temperature and eliminate hot spots. Using external heaters allows the evaluation of internal and external heating methods for process development and scaleup. The reactor is capable of operating at a maximum of $155 \mathrm{psig}$ and $840^{\circ} \mathrm{C}$.

A 3-in.-diameter cyclone is used for solids removal from the gas stream. A ball valve allows the changing of the solids catch pot while the system is operating. The cyclone is heated with a ceramic fiber heater capable of operating at a temperature of $1650^{\circ} \mathrm{F}\left(900^{\circ} \mathrm{C}\right)$ and $200 \mathrm{psig}$. Figure 2 is a schematic of the 8-in.-long section of 2 -in. $316 \mathrm{H}$ stainless steel Schedule 80 pipe constructed specifically for this project to be utilized as a pressure vessel to contain a fixed bed of approximately 1000 grams of zinc oxide sorbent to reduce the $\mathrm{H}_{2} \mathrm{~S}$ levels to less than $10 \mathrm{ppm}$ and preferably to less than $1 \mathrm{ppm}$. Figure 3 is a drawing showing how the zinc oxide sorbent vessel, the $\mathrm{H}_{2}$ separation membrane, a set of gas sampling lines, and ice-cooled knockout pots for removing moisture from the gas samples were installed on the CFBR.

Three 4-in.-diameter vessels are used to remove all condensables from the gas stream. Two separate trains were installed: one for mass balance sampling and the other for heatup, non-steadystate conditions, and cool down. The first condenser pot is indirectly cooled by water and typically cools the gas stream from $570^{\circ} \mathrm{F}\left(300^{\circ} \mathrm{C}\right)$ to $200^{\circ} \mathrm{F}\left(95^{\circ} \mathrm{C}\right)$. The next two condensers, also indirect, are glycol-cooled. The exit gas temperature is typically $50^{\circ} \mathrm{F}\left(10^{\circ} \mathrm{C}\right)$. A glass wool filter was used to capture aerosols passing through the condenser system.

A Genesis $^{\oplus}$ software package is used for process control and data acquisition. Pressure drop across the bed is measured by two transmitters, and thermocouples throughout the unit measure temperatures. Temperature and pressure readings are recorded every 30 seconds, and these data are directly transferred to Lotus ${ }^{\circledR}$ spreadsheets.

Mass flow controllers for hydrogen, carbon monoxide, carbon dioxide, and nitrogen for supplying a clean gas stream from bottled gases were available for temporary use from other projects at the EERC. These mass flow controllers provided a clean gas stream to the CFBR. The CFBR was used as a mixing chamber and heater to generate hot gases for the initial bottled gas membrane tests. These shakedown tests were accomplished without the presence of impurities that would result from of the gasification of coal in the CFBR. All gas analyses were performed on gas bag samples using a Hewlett-Packard 5880 gas chromatograph equipped with a refinery gas analysis package. The refinery gas analysis package provides an analysis equivalent to that specified by Universal Oil Products (UOP) Method 539-73. The gas chromatograph used thermal conductivity detectors and employs two carrier gas streams. Hydrogen and helium are separated and determined in an argon carrier gas stream. In an argon carrier gas, the response for hydrogen is linear over the entire concentration range from $0 \%$ to $100 \%$ hydrogen. The rest of the gas components are separated and determined in a high-purity helium carrier gas stream. The instrument is calibrated daily with 


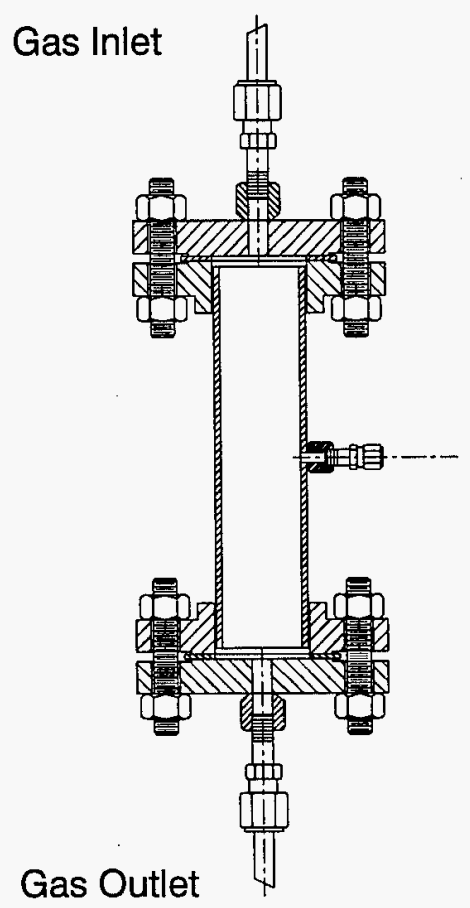

EERC MS11238.CDR

Figure 2. Zinc oxide sorbent vessel.

Certified Grade standard gas mixtures. The minimum detection limit (MDL) for the refinery gas analyzer package is 0.01 mole\% except for $\mathrm{CO}_{2}, \mathrm{CO}, \mathrm{N}_{2}, \mathrm{O}_{2}, \mathrm{CH}_{4}$, and $\mathrm{H}_{2} \mathrm{~S}$, which all have a MDL of 0.02 mole\%. The on-line gas analyzer available at the EERC was not capable of detecting $\mathrm{H}_{2} \mathrm{~S}$ (hydrogen sulfide) levels down to the low levels needed; however, a wet-chemistry method was used to determine the $\mathrm{H}_{2} \mathrm{~S}$ levels leaving the zinc oxide bed. This technique allows $\mathrm{H}_{2} \mathrm{~S}$ concentrations as low as $1 \mathrm{ppm}$ to be measured, but requires a cubic foot of gas per hour to be bubbled though a solution that is then titrated to determine the concentration. This procedure results in a significant delay in obtaining $\mathrm{H}_{2} \mathrm{~S}$ concentration data.

Initial tests were performed to conduct short-term performance tests using the membrane to separate hydrogen from the mixed-gas stream. Subsequent tests then looked at the effects of $\mathrm{H}_{2} \mathrm{~S}$ impurities by injecting a known amount of $\mathrm{H}_{2} \mathrm{~S}$ into the gas stream. One operational problem encountered in performing the bottled gas tests was the formation of fine carbon particles from the reaction of carbon monoxide with itself to form carbon dioxide and carbon. This fine carbon blocked flow through the distributor plate of the CFBR and blocked the pressure taps on the CFBR, which resulted in shutting down the CFBR three times to either clear the distributor plate or the pressure taps. Further testing examined the effect of other impurities (such as $\mathrm{H}_{2} \mathrm{~S}, \mathrm{HCl}$, etc.) by operating the membrane using actual coal-derived fuel gases from the same CFBR equipment. The gas composition of the coal-derived gas stream was adjusted by adding some bottled hydrogen gas to the gas stream entering the reactor. Table 1 shows the results of proximate and ultimate analyses of the coal used to provide the coal-derived fuel gas for the testing of the membranes. The Wyodak subbituminous coal from the Powder River Basin was selected since its low sulfur and ash levels would allow the lower $\mathrm{H}_{2} \mathrm{~S}$ contaminant levels desired by the Bend Research, Inc., membrane. To 


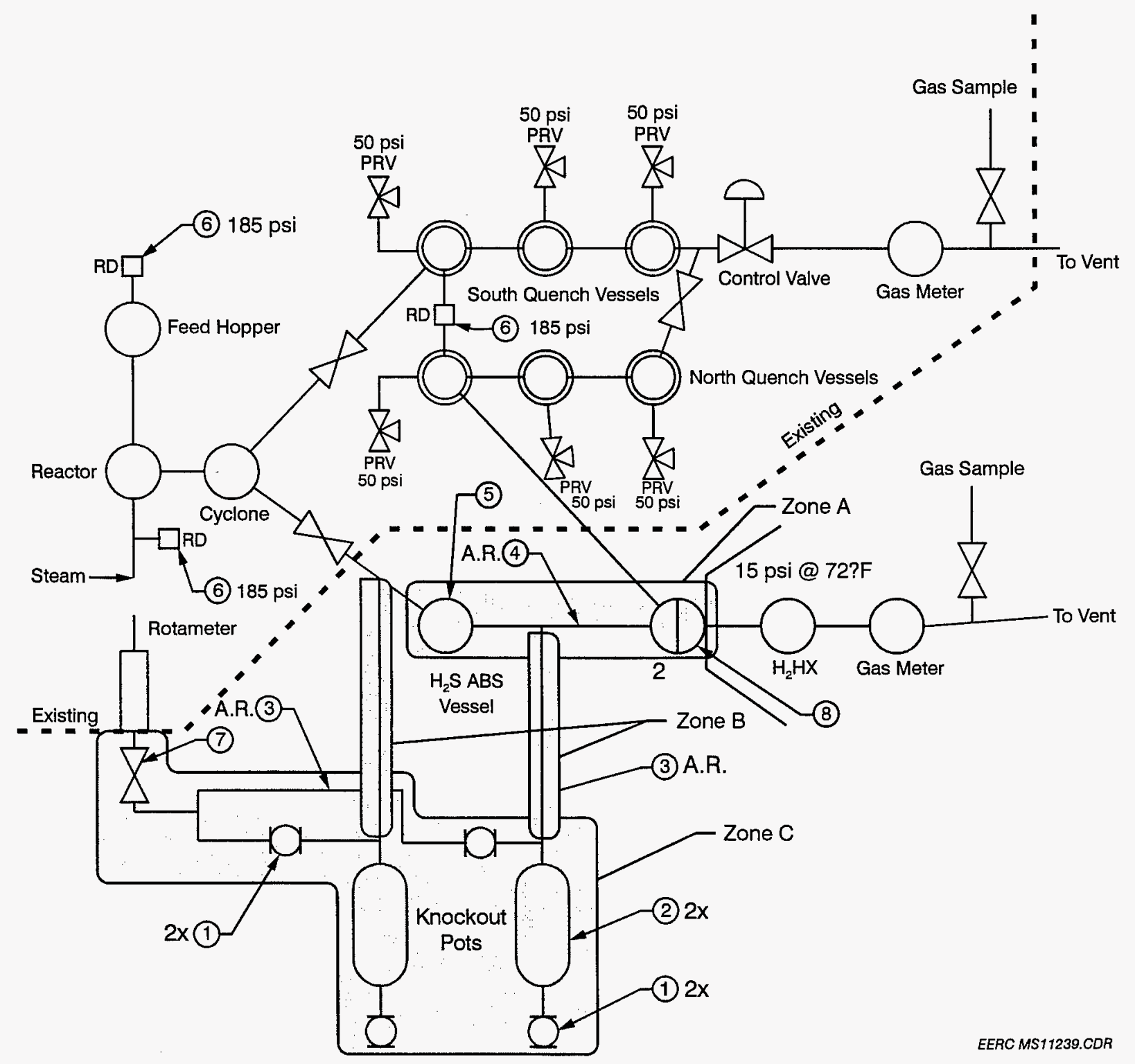

Figure 3. Piping modifications on the 4-lb/hr CFBR. 


\section{TABLE 1}

Proximate and Ultimate Analyses of Wyodak Subbituminous Coal from the Powder River Basin Mixed with $\mathrm{CaCO}_{3}$

\begin{tabular}{lcc}
\hline Wyodak Subbituminous & As-Run & Moisture-Free \\
\hline Proximate Analysis & & \\
Moisture & 28.2 & NA \\
Volatile Matter & 31.22 & 43.48 \\
Fixed Carbon & 34.46 & 47.99 \\
Ash & 6.11 & 8.51 \\
Ultimate Analysis & & \\
Hydrogen & 6.21 & 4.28 \\
Carbon & 47.08 & 65.57 \\
Nitrogen & 0.56 & 0.78 \\
Sulfur & 0.42 & 0.58 \\
Oxygen, ind. & 39.59 & 20.23 \\
Ash & 6.11 & 8.51 \\
Heating Value, Btu/lb & 7,953 & 11,077 \\
\hline
\end{tabular}

reduce the $\mathrm{H}_{2} \mathrm{~S}$ levels further, solid $\mathrm{CaCO}_{3}$ was added to the fuel at $3 \mathrm{wt} \%$ to capture as much of the sulfur as possible in the bed.

\subsection{Experimental Results}

Table 2 shows the operating conditions at which the bottled gas tests were performed on the 0.03-mm-thick Pd/Ag membrane. After the first membrane was exposed to $\mathrm{H}_{2} \mathrm{~S}$, a new membrane was installed after Test M453 for the coal gas test.

Table 3 shows the operating conditions from product gas tests utilizing a 0.06 -mm-thick palladium membrane using both a bottled gas baseline test and a coal-gas-derived baseline test, after which the membrane was exposed to $10 \mathrm{ppm}_{2} \mathrm{~S}$ to speed up the membrane deterioration process. Figures 4-6 show the measured permeate flow rates for the three membranes tested as a function of the total run time on each membrane. In these figures, every change in a run condition is indicated. From Figures 4 and 5, it appears that operating at higher temperatures increased the hydrogen permeability. Running at a higher partial pressure increased the permeate flow rate but did not increase the permeability of hydrogen, indicating that flow across the membrane is controlled by molecular sieving. The addition of $\mathrm{H}_{2} \mathrm{~S}$ (even at levels down to $1 \mathrm{ppm}$ ) to the bottled gas mixture significantly reduced the permeate flow rates. The initial gas flow rates used in these tests were comparable to those expected from a coal-derived gas stream. In an effort to save on bottled gas consumption and to determine the effect of product gas flow rate through the membrane, the product gas flow rate was reduced by approximately one-half after Test M451. The reduction of the flow rate of product gas through the membrane (Test 452) did not appear to change the hydrogen permeability from the $500^{\circ}$ bottled gas baseline. However, it appears the possible shutdown of the product gas flow through the membrane for 3 hours to clear plugged pressure taps on the CFBR probably allowed the $\mathrm{H}_{2} \mathrm{~S}$ contaminant from Test M451 to be removed via some reversible equilibrium reaction. From these figures, it is apparent that as soon as the $\mathrm{H}_{2} \mathrm{~S}$ addition was stopped, the permeate flow rates would increase significantly. 
TABLE 2

Operating Conditions from Product Gas Tests on $\mathrm{Pd} / \mathrm{Ag}$ Membrane

\begin{tabular}{lcllllll}
\hline $\begin{array}{l}\text { Run Number: } \\
\text { Gas Source: }\end{array}$ & $\begin{array}{l}\text { M449 } \\
\text { Bottle }\end{array}$ & $\begin{array}{l}\text { M450 } \\
\text { Bottle }\end{array}$ & $\begin{array}{l}\text { M451 } \\
\text { Bottle }\end{array}$ & $\begin{array}{l}\text { M452 } \\
\text { Bottle }\end{array}$ & $\begin{array}{l}\text { M453 } \\
\text { Bottle }\end{array}$ & $\begin{array}{l}\text { M454 } \\
\text { Bottle }\end{array}$ & $\begin{array}{l}\text { M455 } \\
\text { Coal Gas }\end{array}$ \\
\hline Temperature, ${ }^{\circ} \mathrm{C}$ & 400 & 500 & 500 & 500 & 500 & 500 & 500 \\
$\mathrm{H}_{2}$ Part. Pres., psia & 41.8 & 38.3 & 41.7 & 40.8 & 39.9 & 71.8 & 28.2 \\
Inlet Gas Flow Rates, scfh & & & & & & & \\
$\mathrm{H}_{2}$ & 54 & 47.4 & 53 & 19.6 & 20.2 & 35 & 21 \\
$\mathrm{~N}_{2}$ & 74.2 & 71.2 & 72 & 27.8 & 29 & 17.5 & 132 \\
$\mathrm{CO}_{2}$ & 21.2 & 21.2 & 21.2 & 8 & 8 & 6 & NF $^{1}$ \\
$\mathrm{CO}$ & 21.2 & 21.2 & 21.2 & 8 & 8 & 6 & NF \\
$\mathrm{H}_{2} \mathrm{O}$ & 42.1 & 42.1 & 42.1 & 15.8 & 15.8 & 15.8 & 53.3 \\
$\mathrm{H}_{2}$ S Conc., ppm & 0 & 0 & 1 & 0 & 10 & 0 & $<5$ \\
Coal Feed Rate, lb/hr & 0 & 0 & 0 & 0 & 0 & 0 & 1.5 \\
\hline
\end{tabular}

${ }^{1}$ Not fed.

TABLE 3

Operating Conditions from Product Gas Tests Using Palladium Membrane

\begin{tabular}{lccc}
\hline $\begin{array}{l}\text { Run Number: } \\
\text { Gas Source: }\end{array}$ & $\begin{array}{c}\text { M456 } \\
\text { Bottle }\end{array}$ & $\begin{array}{l}\text { M457A } \\
\text { Coal Gas }\end{array}$ & $\begin{array}{c}\text { M457B } \\
\text { Coal Gas w/H }\end{array}$ \\
\hline Temperature, ${ }^{\circ} \mathrm{C}$ & 500 & 500 & 500 \\
$\mathrm{H}_{2}$ Part. Pres., psia & 40.8 & 26.3 & 26.6 \\
Inlet Gas Flow Rates, scfh & & & \\
$\mathrm{H}_{2}$ & 20.0 & 22 & 22 \\
$\mathrm{~N}_{2}$ & 29.0 & 135 & 135 \\
$\mathrm{CO}_{2}$ & 8.0 & 0 & 0 \\
$\mathrm{CO}$ & 8.0 & 0 & 0 \\
$\mathrm{H}_{2} \mathrm{O}$ & 15.8 & 49.4 & 49.4 \\
$\mathrm{H}_{2} \mathrm{~S} \mathrm{Conc.,} \mathrm{ppm}$ & 0 & $<5$ & $>10$ \\
$\mathrm{Coal} \mathrm{Feed} \mathrm{Rate,} \mathrm{lb/hr}$ & 0 & 1.5 & 1.5 \\
\hline
\end{tabular}

While these flow rates would not return to their previous levels, they would increase by over a factor of two very rapidly, presumably as some of the $\mathrm{H}_{2} \mathrm{~S}$ contaminant on the surface of the membrane was reversibly removed via a reaction or just vaporized off as elemental sulfur. Approximately 5 hours into the coal-derived fuel gas test (Test M455) on the second palladium-silver (Pd-Ag) membrane, a couple of valves, which were used to take gas samples from either upstream or downstream of the zinc oxide sorbent bed, were accidentally left open at the same time, allowing some of the high- $\mathrm{H}_{2} \mathrm{~S}$ $(\approx 280 \mathrm{ppm})$ fuel gas to bypass the zinc oxide bed. This reduced the permeate flow rate to near zero in a matter of a few minutes and it did not recover substantially on the coal gas after the valves were closed. Excluding the portion of the test where the zinc oxide bed was bypassed, the $\mathrm{H}_{2} \mathrm{~S}$ concentrations were determined to be less than $1 \mathrm{ppm}$ during the early part of the test and had 


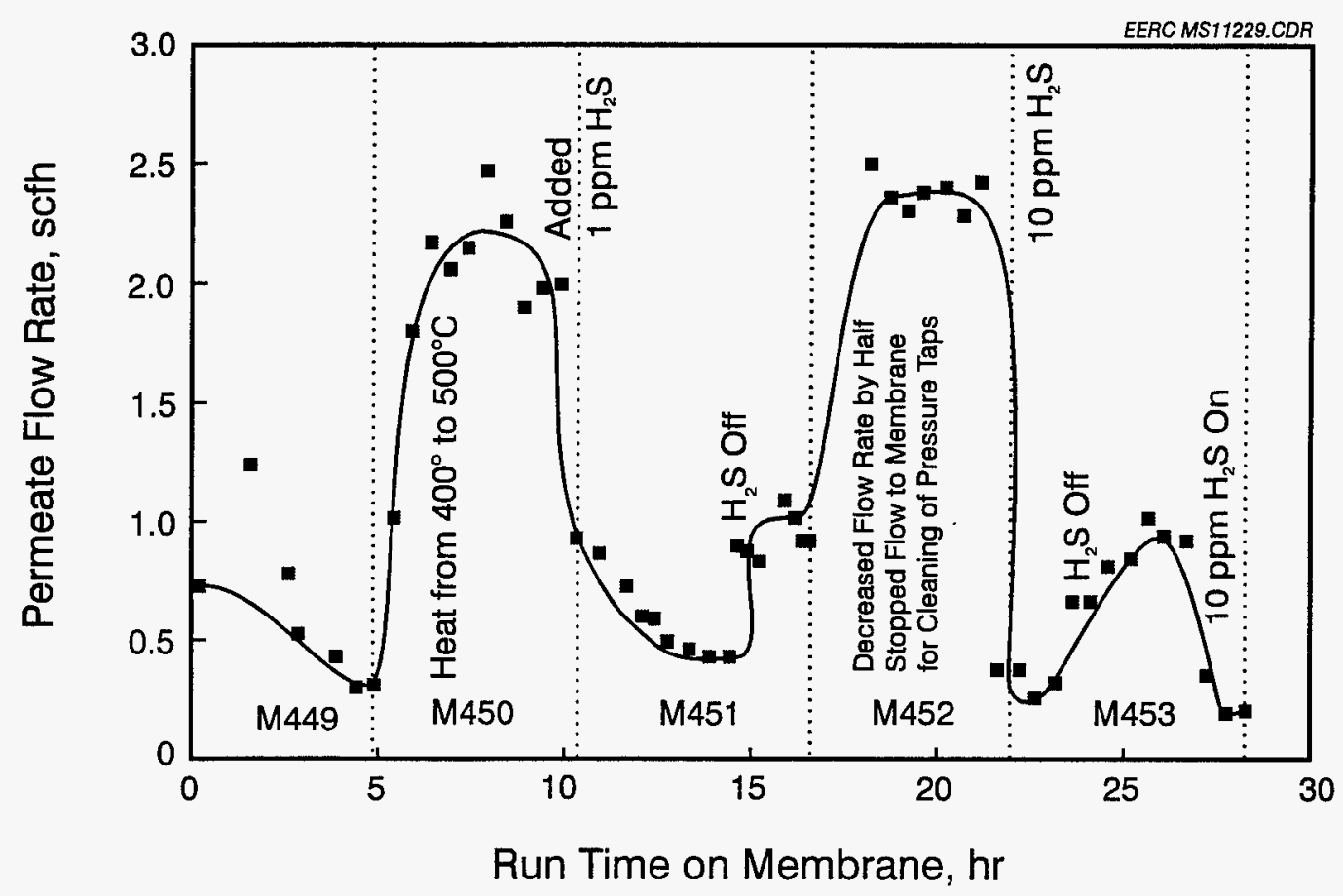

Figure 4. Permeate flow rate versus run time for Membrane 1 tested at various conditions on the CFBR.

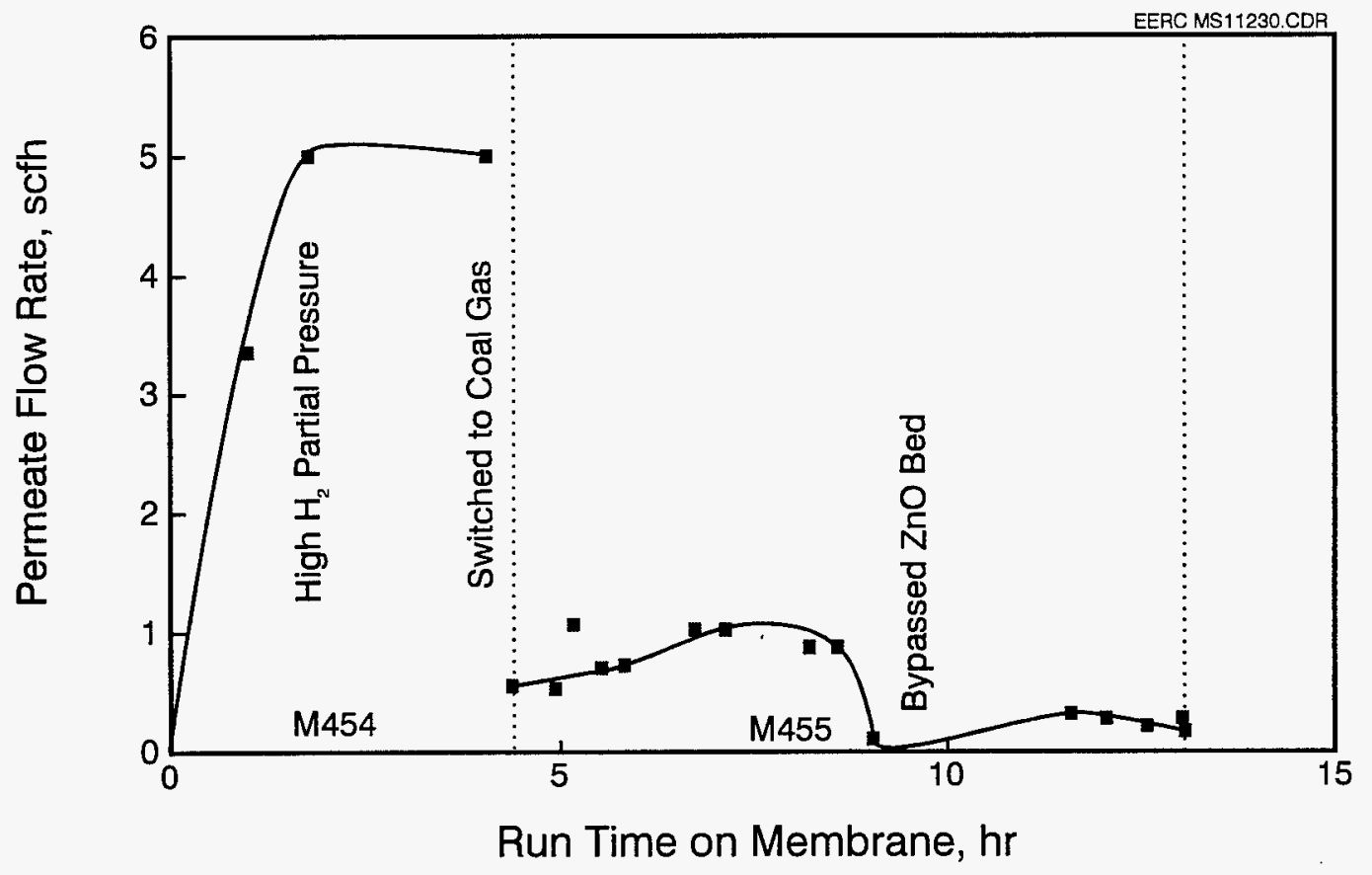

Figure 5. Permeate flow rate versus run time for Membrane 2 tested at various conditions on the CFBR. 


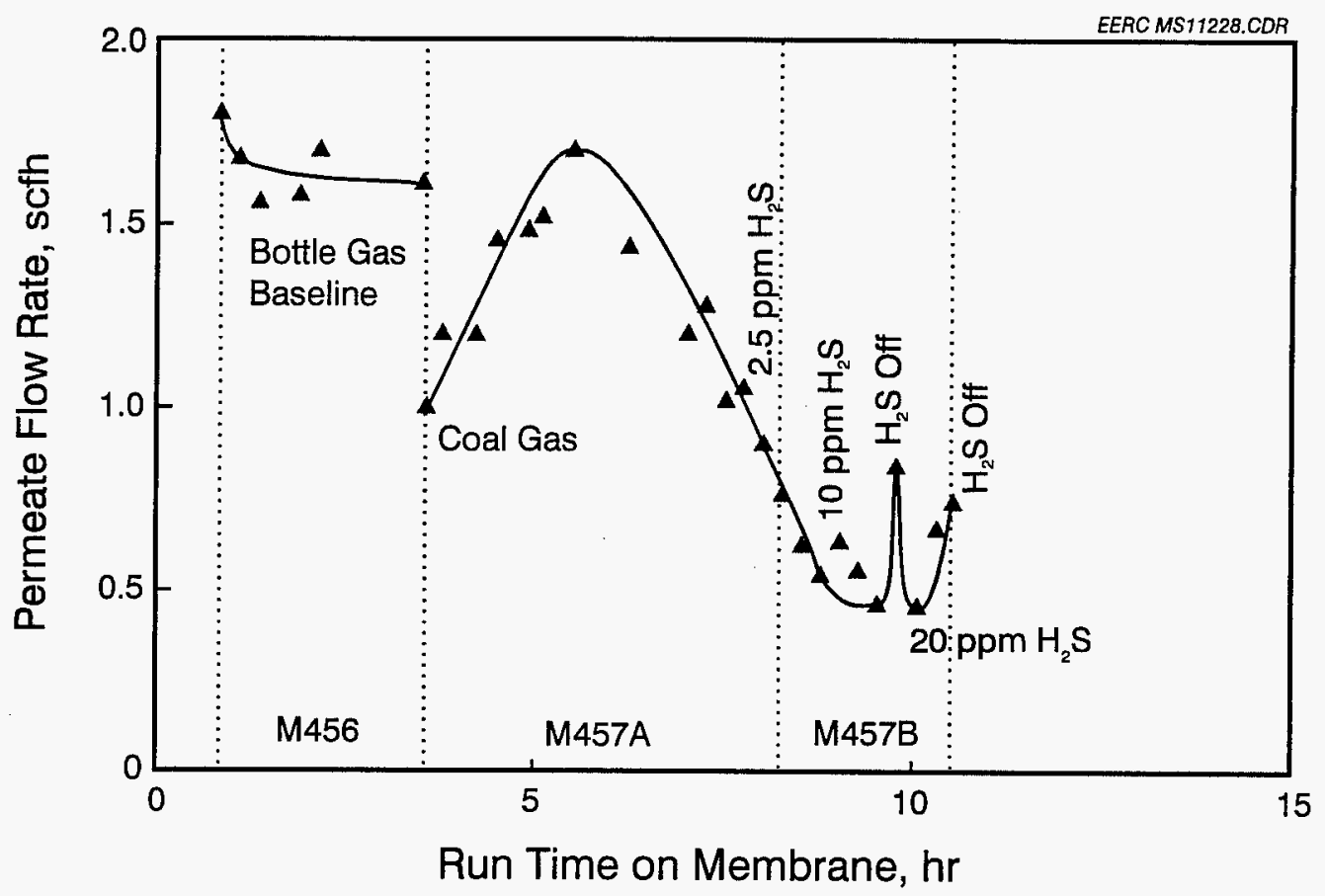

Figure 6. Permeate flow rate versus run time for Membrane 3 tested at various conditions on the CFBR.

increased to over $4 \mathrm{ppm}$ by the end of the test on the membrane. The continued presence of $\mathrm{H}_{2} \mathrm{~S}$ in the fuel gas after the valves were shut probably limited the amount the membrane could recover.

The decrease in the baseline permeate flow rate for the third membrane is partially the result of the thickness $(0.06 \mathrm{~mm})$ of the all-palladium membrane as opposed to the two Pd-Ag membranes $(0.03 \mathrm{~mm})$. The Pd membrane was definitely affected by the presence of the $\mathrm{H}_{2} \mathrm{~S}$ in the product gas but did not appear to be as sensitive as the Pd-Ag membranes were.

Tables 4-6 show the gas analysis results of the feed gas, raffinate, and permeate streams taken for these tests. These tables also show the gas analysis results for the permeate gas stream after correcting for some dilution effects that resulted from the purging of the gas bags with nitrogen before they were evacuated with a vacuum pump. This correction assumed that the $\mathrm{N}_{2}$ permeability would be equal to that of the $\mathrm{CO}$ (because of their similar molecular weights), and thus the ratio of $\mathrm{N}_{2}$ to $\mathrm{CO}$ in the permeate gas stream should be the same as the ratio of $\mathrm{N}_{2}$ to $\mathrm{CO}$ in the feed gas stream.

A common measure of membrane performance is its separation factor, which is defined in the following equation as (1):

$$
\alpha_{i j}=\frac{Y_{i} / X_{i}}{Y_{j} / X_{j}}
$$


where $\alpha_{\mathrm{ij}}=$ separation factor (dimensionless)

$Y_{i}=$ mole fraction of component $i$ in permeate

$\mathrm{Y}_{\mathrm{j}}=$ mole fraction of component $\mathrm{j}$ in permeate

$\mathrm{X}_{\mathrm{i}}=$ mole fraction of component $\mathrm{i}$ in feed

$\mathrm{X}_{\mathrm{j}}=$ mole fraction of component $\mathrm{j}$ in feed

Separation factors for these product gas tests on the Bend Research, Inc., membranes are shown in Table 7. The permeability results have been reported as a permeate gas flow rate per unit component partial pressure drop across the membrane per unit membrane surface area (i.e., $\mathrm{m}^{3} / \mathrm{hr}$ atm $-\mathrm{m}^{2}$ ). These results are also displayed in Table 7.

These values indicate that high separation factors can be achieved with these membranes, since the premeabilities of the undesired gases is very low. However, the permeability of hydrogen gas is also much lower than those reported for ceramic membranes (2).

Figures 7 and 8 show the hydrogen permeability for these tests as determined from the permeate flow rates and gas analyses. The hydrogen permeabilities again indicate how sensitive the palladium-based membranes are to hydrogen sulfide in the feed gas. The permeability also is significantly affected by membrane temperature or hydrogen partial pressure, but does not appear to be significantly affected by product gas feed rate through the membrane.

$\mathrm{X}$-ray photoelectron spectroscopy was performed on a prototype hydrogen-permeable membrane produced by Bend Research, Inc. The membrane was exposed to hydrogen sulfide in the CFBR during a test to simulate coal gasification conditions. The objective of the analysis was to determine the composition of a thin white coating that was deposited on the retentate side of the membrane during the test run. In photoelectron spectroscopy, a sample is irradiated with photons of a known energy, which ionize the sample and result in the ejection of electrons. By measuring the kinetic energy of the electrons, we can determine their binding energies in the atoms from which they came. Since all elements have characteristic binding energies for electron shells, one can determine from which element an electron of a given energy came. Thus using this technique, we can determine the composition of an unknown. By looking at subtle shifts in binding energies produced in the chemical formation of compounds, we can also determine the chemical state of elements by this method.

For this analysis, a $1253.7 \mathrm{eV} \mathrm{mg} \mathrm{x}$-ray source was used at $10 \mathrm{kv}$ and 350 watts power. A wide energy scan was performed using electron spectroscopy for chemical analyses (ESCA) to determine the elements present. Figure 9 shows this scan with the major elements identified. The elements found were palladium, silver, and sulfur. Since the membrane is a palladium-silver alloy, the deposit was assumed to be composed of a a sulfur compound. A narrow energy scan, shown in Figure 10, was next performed to determine the state of the sulfur. The binding energies of the peaks were compared to those determined by Wagner and others (3). From these data, the deposit appears to be predominantly elemental sulfur emitting at $163.74 \mathrm{eV}$, with a small quantity of a sulfate-like compound emitting at $168.6 \mathrm{eV}$.

\subsection{FUTURE WORK}

This project will be continuing under the DOE Cooperative Agreement as Task 6.5 - Materials for Gas Separation and Hot-Gas Cleanup under the overall Task 6.0 - High-Temperature Materials program. The objective of this task will be to develop and test gas separation membranes to be developed with an EERC proprietary process. The remainder of this project was spent performing a literature review to ensure that this EERC process does not duplicate other techniques developed 


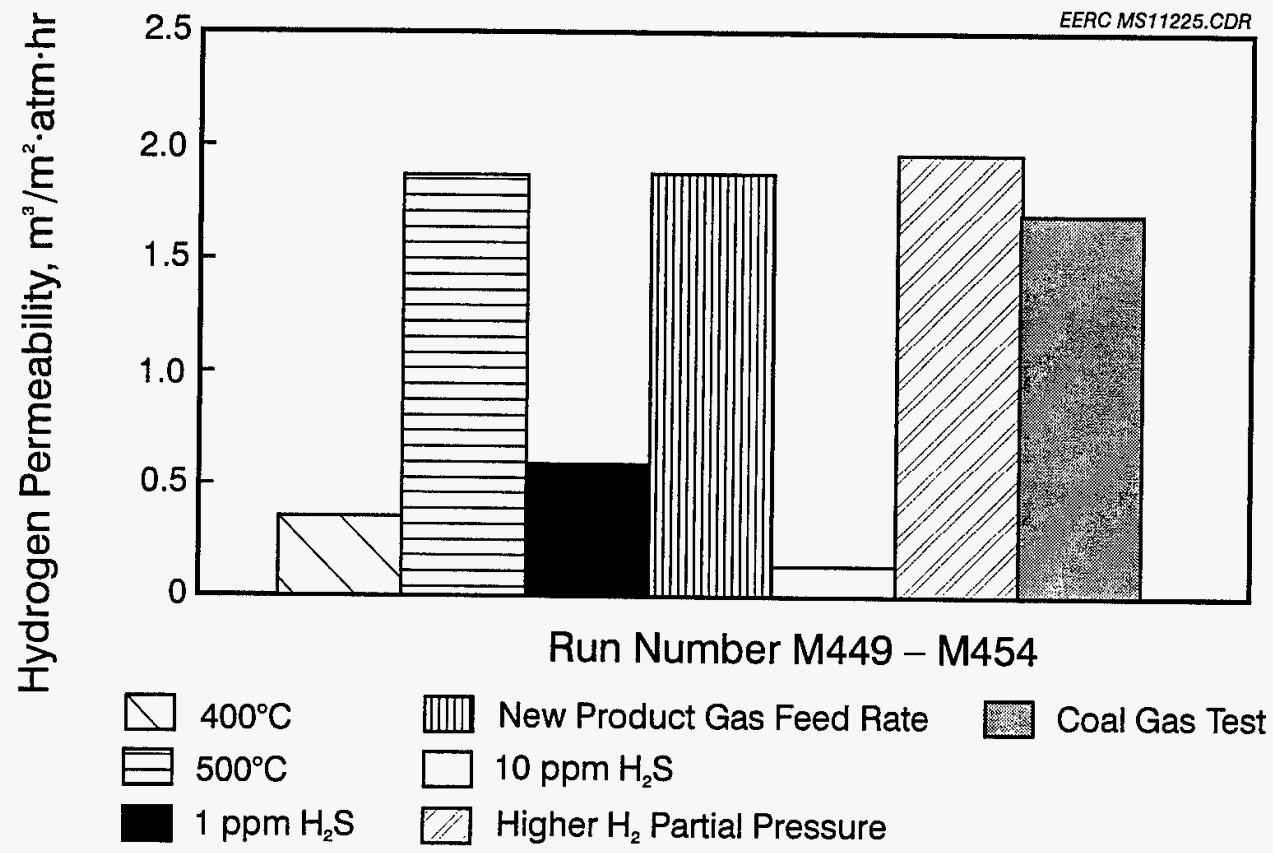

Figure 7. Comparison of $\mathrm{H}_{2}$ permeability for bottled gas and coal gas tests in the CFBR using Pd-Ag membrane.

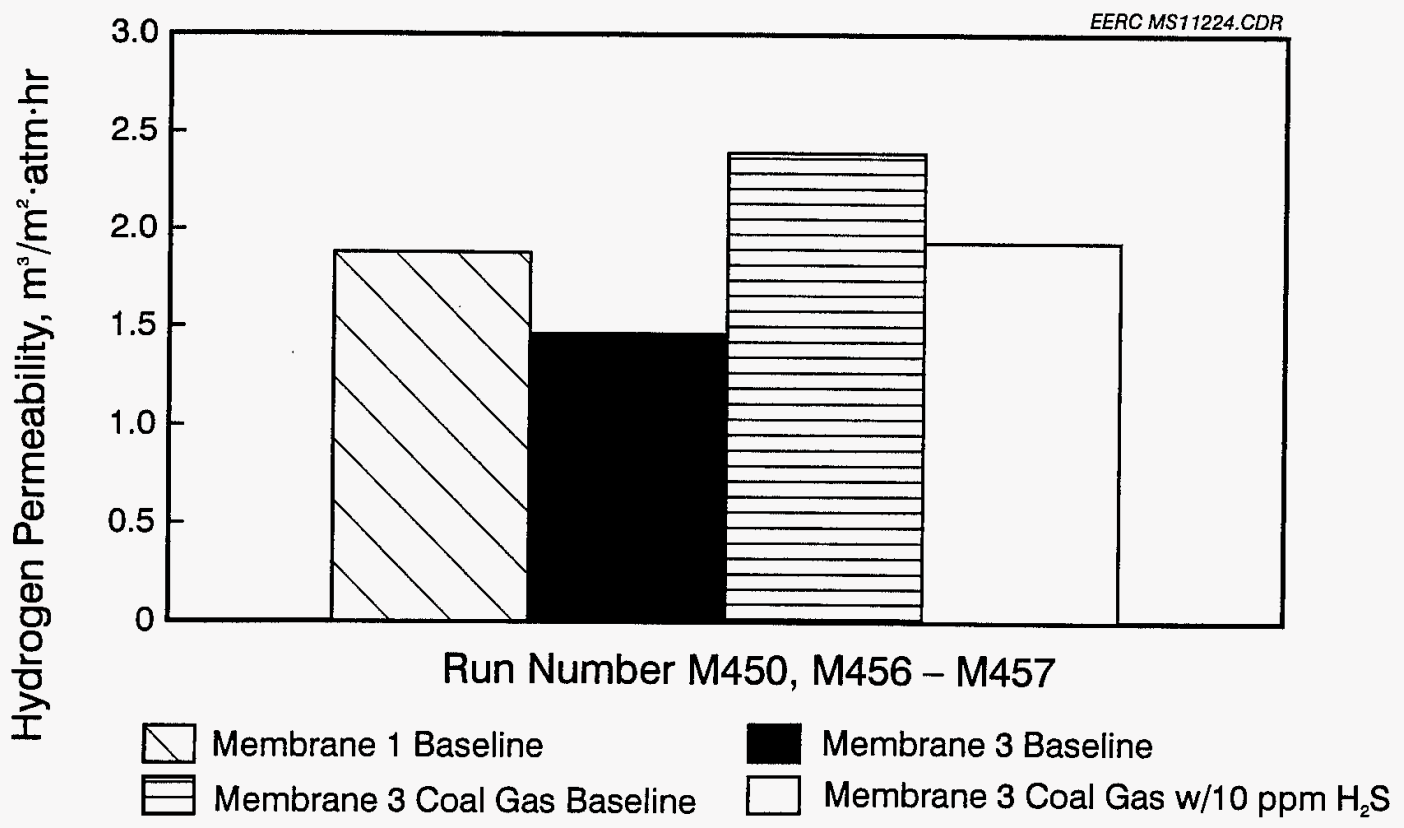

Figure 8. $\mathrm{H}_{2}$ permeability for bottled gas and coal gas tests in the CFBR using palladium membrane as compared to Pd-Ag membrane baseline. 


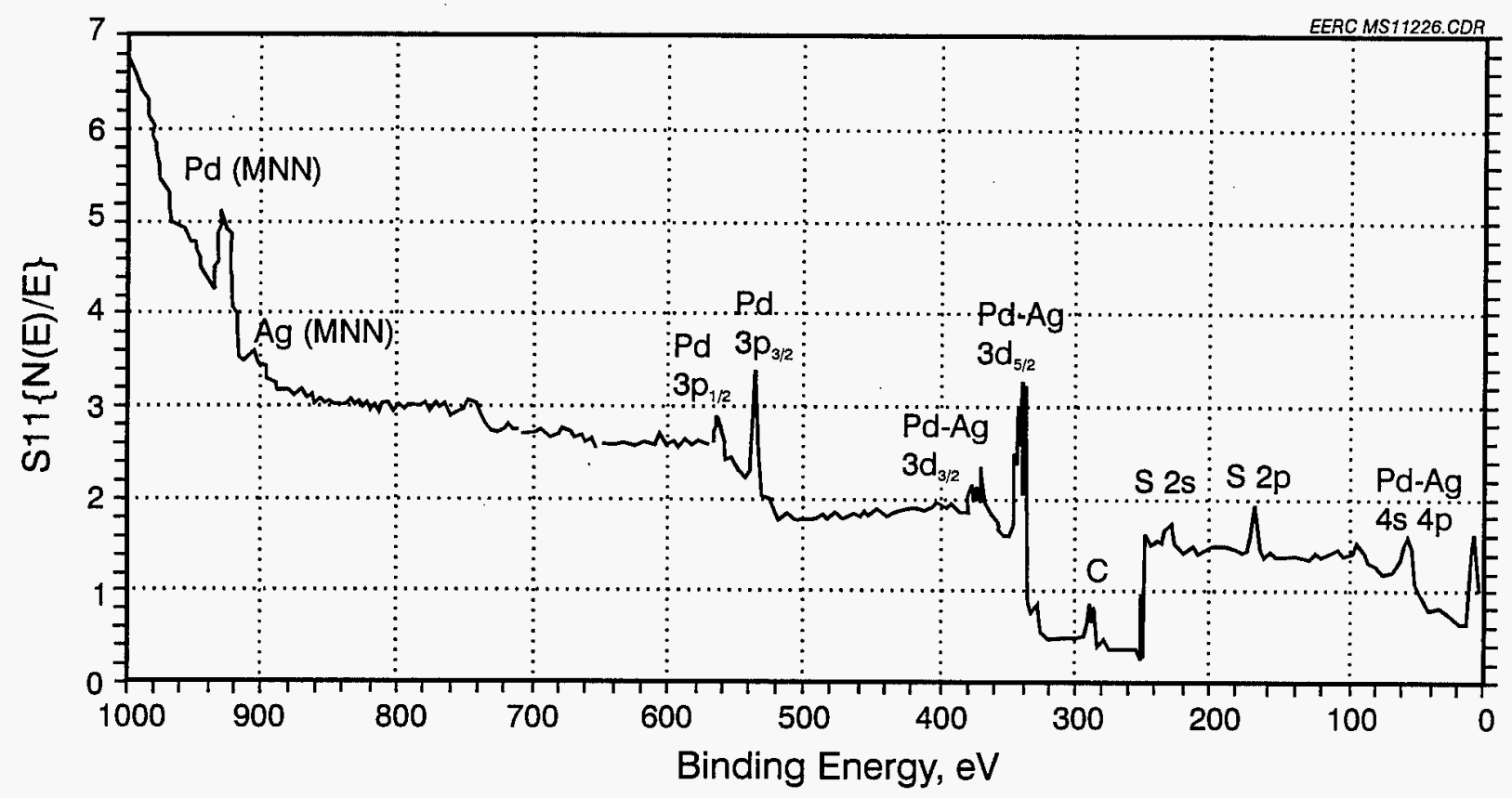

Figure 9. ESCA analysis of Pd-Ag membrane with deposited layer on the feed gas side of the membrane.

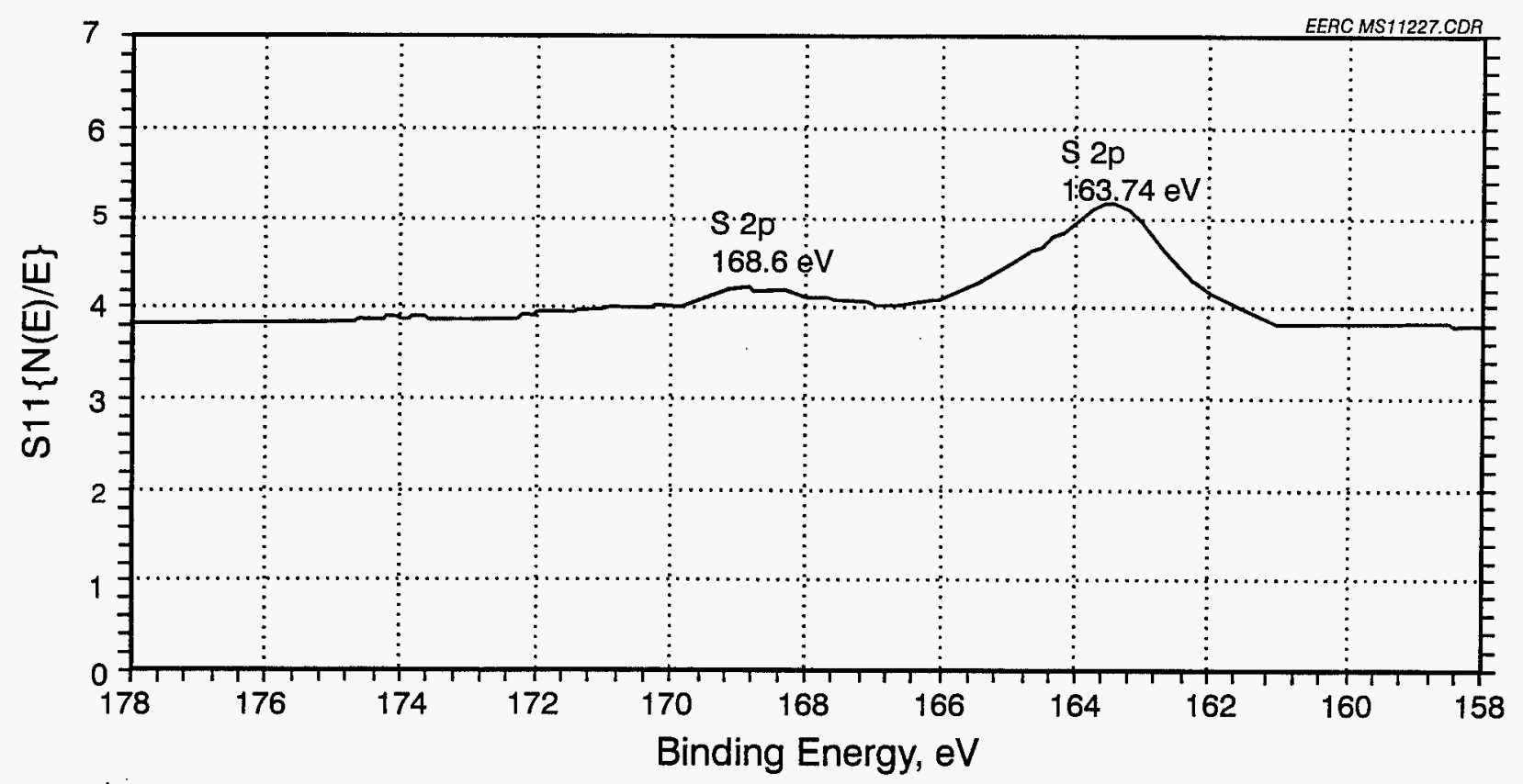

Figure 10. Detailed ESCA analysis of Pd-Ag membrane identifying deposited layer as elemental sulfur. 
TABLE 4

Gas Chromatograph Data from Bottled Gas Tests on Pd-Ag Membrane Including Corrected Data from Permeate Gas Stream

\begin{tabular}{|c|c|c|c|c|c|c|c|c|c|c|c|c|c|c|c|c|}
\hline $\begin{array}{l}\text { Run Number } \\
\text { Sample Type }\end{array}$ & $\begin{array}{l}\text { M449 } \\
\text { Feed } \\
\end{array}$ & $\begin{array}{l}\text { M449 } \\
\text { Raf. }\end{array}$ & $\begin{array}{l}\text { M449 } \\
\text { Per. }\end{array}$ & $\begin{array}{l}\text { Cor. } \\
\text { Per. }\end{array}$ & $\begin{array}{l}\text { M450 } \\
\text { Feed }\end{array}$ & $\begin{array}{l}\text { M450 } \\
\text { Raf. }\end{array}$ & $\begin{array}{l}\text { M450 } \\
\text { Per. }\end{array}$ & $\begin{array}{l}\text { Cor. } \\
\text { Per. }\end{array}$ & $\begin{array}{l}\text { M451 } \\
\text { Feed } \\
\end{array}$ & $\begin{array}{l}\text { M451 } \\
\text { Raf. }\end{array}$ & $\begin{array}{l}\text { M451 } \\
\text { Per. }\end{array}$ & $\begin{array}{l}\text { Cor. } \\
\text { Per. }\end{array}$ & $\begin{array}{l}\text { M452 } \\
\text { Feed }\end{array}$ & $\begin{array}{l}\text { M452 } \\
\text { Raf. }\end{array}$ & $\begin{array}{l}\text { M452 } \\
\text { Per. }\end{array}$ & $\begin{array}{l}\text { Cor. } \\
\text { Per. }\end{array}$ \\
\hline \multicolumn{17}{|c|}{$\begin{array}{l}\text { Gas Composition, } \\
\text { mol\% }\end{array}$} \\
\hline $\mathrm{H}_{2}$ & 32.6 & 31.4 & 84.6 & 86.3 & 32.6 & 30.3 & 98.7 & 99.7 & 32.0 & 32.1 & 97.4 & 98.8 & 30.1 & 30.8 & 90.2 & 94.0 \\
\hline $\mathrm{N}_{2}$ & 42.8 & 43.5 & 10.2 & 8.6 & 42.8 & 45.0 & 0.95 & 0.21 & 43.5 & 43.7 & 1.88 & 0.73 & 56.3 & 47.6 & 8.50 & 4.74 \\
\hline $\mathrm{CO}_{2}$ & 11.8 & 12.6 & 2.53 & 2.6 & 11.8 & 12.3 & 0.07 & 0.07 & 12.3 & 12.4 & 0.24 & 0.24 & 6.45 & 11.49 & 0.65 & 0.68 \\
\hline $\mathrm{CO}^{2}$ & 12.4 & 12.1 & 2.44 & 2.5 & 12.4 & 12.0 & 0.06 & 0.06 & 12.0 & 11.7 & 0.20 & 0.20 & 6.93 & .56 & 0.56 & 0.58 \\
\hline $\mathrm{CH}_{4}$ & 0.0 & 0.0 & 0.0 & 0.0 & 0.0 & 0.0 & 0.0 & 0.0 & 0.0 & 0.0 & 0.0 & 0.0 & 0.08 & 0.06 & 0.0 & 0.0 \\
\hline $\mathrm{He}$ & 0.02 & 0.01 & 0.02 & 0.0 & 0.02 & 0.15 & 0.11 & 0.0 & 0.02 & 0.04 & 0.02 & 0.0 & 0.04 & 0.03 & 0.02 & 0.0 \\
\hline $\mathrm{O}_{2} / \mathrm{Ar}$ & 0.3 & 0.36 & 0.22 & 0.0 & 0.3 & 0.15 & 0.10 & 0.0 & 0.15 & 0.05 & 0.24 & 0.0 & 0.05 & 0.55 & 0.04 & 0.0 \\
\hline Total & 100 & 100 & 99.9 & 100 & 100 & 99.9 & 100 & 100 & 100 & 100 & 99.9 & 100 & 99.9 & 100 & 100 & 100 \\
\hline
\end{tabular}

\section{TABLE 5}

Gas Chromatograph Data from Bottled Gas and Coal Gas Tests on Pd-Ag Membrane Including Corrected Data from Permeate Gas Stream

\begin{tabular}{|c|c|c|c|c|c|c|c|c|c|c|c|c|}
\hline $\begin{array}{l}\text { Run Number } \\
\text { Sample Type }\end{array}$ & & $\begin{array}{c}\text { M453A } \\
\text { Raf. } \\
\end{array}$ & $\begin{array}{c}\text { M453A } \\
\text { Per. }\end{array}$ & $\begin{array}{l}\text { Cor. } \\
\text { Per. }\end{array}$ & $\begin{array}{c}\text { M453B } \\
\text { Raf. } \\
\end{array}$ & $\begin{array}{c}\text { M453B } \\
\text { Per. }\end{array}$ & $\begin{array}{l}\text { Cor. } \\
\text { Per. }\end{array}$ & $\begin{array}{c}\text { M454 } \\
\text { Feed } \\
\end{array}$ & $\begin{array}{c}\text { M454 } \\
\text { Raf. }\end{array}$ & $\begin{array}{c}\text { M454 } \\
\text { Per. }\end{array}$ & $\begin{array}{c}\text { M455 } \\
\text { Feed }\end{array}$ & $\begin{array}{c}\text { M455 } \\
\text { Per. }\end{array}$ \\
\hline \multicolumn{13}{|c|}{$\begin{array}{l}\text { Gas Composition, } \\
\text { mol\% }\end{array}$} \\
\hline $\mathrm{H}_{2}$ & 31.1 & 32.4 & 79.3 & 85.3 & 31.7 & 73.1 & 84.7 & 55.9 & 28.6 & 98.9 & 20.2 & 98.9 \\
\hline $\mathrm{N}_{2}$ & 44.9 & 49.1 & 15.4 & 9.31 & 48.8 & 20.2 & 9.26 & 27.6 & 44.8 & 1.09 & 73.0 & 1.02 \\
\hline $\mathrm{CO}_{2}$ & 12.0 & 9.77 & 2.72 & 2.92 & 10.8 & 2.90 & 3.36 & 9.37 & 16.3 & 0.0 & 4.40 & 0.0 \\
\hline $\mathrm{CO}^{2}$ & 12.0 & 8.26 & 2.31 & 2.48 & 8.26 & 2.28 & 2.64 & 6.91 & 10.2 & 0.0 & 1.37 & 0.0 \\
\hline $\mathrm{CH}_{4}$ & 0.0 & 0.09 & 0.0 & 0.0 & 0.14 & 0.0 & 0.0 & 0.13 & 0.12 & 0.0 & 0.99 & 0.0 \\
\hline $\mathrm{He}$ & 0.0 & 0.15 & 0.04 & 0.0 & 0.02 & 0.02 & 0.0 & 0.01 & 0.01 & 0.02 & 0.02 & 0.01 \\
\hline $\mathrm{O}_{2} / \mathrm{Ar}$ & 0.0 & 0.29 & 0.22 & 0.0 & 0.33 & 1.59 & 0.0 & 0.04 & 0.05 & 0.03 & 0.17 & 0.04 \\
\hline Total & 100 & 100 & 100 & 100 & 100 & 100 & 100 & 100 & 100 & 100 & 100 & 100 \\
\hline
\end{tabular}

Note: No correction was applied to M454 and M455 tests as no CO was detected in permeate gas stream. 
TABLE 6

Gas Chromatograph Data from Bottled Gas and Coal Gas Tests on Palladium Membrane

\begin{tabular}{lcccccccc}
\hline $\begin{array}{l}\text { Run Number: } \\
\text { Sample Type: }\end{array}$ & $\begin{array}{c}\text { M456 } \\
\text { Feed }\end{array}$ & $\begin{array}{c}\text { M456 } \\
\text { Raf. }\end{array}$ & $\begin{array}{c}\text { M456 } \\
\text { Per. }\end{array}$ & $\begin{array}{c}\text { M457 } \\
\text { Feed }\end{array}$ & $\begin{array}{c}\text { M457A } \\
\text { Raf. }\end{array}$ & $\begin{array}{c}\text { M457A } \\
\text { Per. }\end{array}$ & $\begin{array}{c}\text { M457B } \\
\text { Raf. }\end{array}$ & $\begin{array}{c}\text { M457B } \\
\text { Per. }\end{array}$ \\
\hline Gas Composition, mol\% & & & & & & & \\
$\mathrm{H}_{2}$ & 24.1 & 24.7 & 99.7 & 20.2 & 21.2 & 98.5 & 22.1 \\
$\mathrm{~N}_{2}$ & 54.5 & 48.9 & 0.21 & 73.0 & 71.8 & 1.25 & 69.3 & 1.39 \\
$\mathrm{CO}_{2}$ & 7.23 & 9.54 & 0.0 & 4.20 & 4.44 & 0.01 & 4.77 & 0.07 \\
$\mathrm{CO}$ & 13.1 & 15.7 & 0.0 & 1.37 & 1.43 & 0.0 & 2.82 & 0.0 \\
$\mathrm{CH}_{4}$ & 1.01 & 1.10 & 0.0 & 0.99 & 0.99 & 0.0 & 0.72 & 0.0 \\
$\mathrm{He}$ & 0.06 & 0.02 & 0.09 & 0.02 & 0.02 & 0.05 & 0.02 & 0.21 \\
$\mathrm{O}_{2}$ :Ar & 0.04 & 0.1 & 0.04 & 0.17 & 0.08 & 0.22 & 0.23 & 0.27 \\
Total & 100.0 & 100.1 & 100.0 & 100.0 & 100.0 & 100.0 & 100.0 & 100.0 \\
\hline
\end{tabular}

TABLE 7

Separation Factors and Permeabilities of Corrected Permeate Gases Through Pd-Ag and Pd Membranes

\begin{tabular}{|c|c|c|c|c|c|c|c|c|c|c|c|}
\hline $\begin{array}{l}\text { Run Number: } \\
\text { Sample Type: }\end{array}$ & $\begin{array}{l}\text { M449 } \\
\text { Per. }\end{array}$ & $\begin{array}{l}\text { M450 } \\
\text { Per. }\end{array}$ & $\begin{array}{c}\text { M451 } \\
\text { Per. }\end{array}$ & $\begin{array}{c}\text { M452 } \\
\text { Per. } \\
\end{array}$ & $\begin{array}{c}\text { M453A } \\
\text { Per. }\end{array}$ & $\begin{array}{c}\text { M453B } \\
\text { Per. }\end{array}$ & $\begin{array}{c}\text { M454 } \\
\text { Per. }\end{array}$ & $\begin{array}{c}\text { M455 } \\
\text { Per. }\end{array}$ & $\begin{array}{c}\text { M456 } \\
\text { Per. }\end{array}$ & $\begin{array}{c}\text { M457A } \\
\text { Per. }\end{array}$ & $\begin{array}{c}\text { M457B } \\
\text { Per. }\end{array}$ \\
\hline \multicolumn{12}{|c|}{ Separation Factor ${ }^{a}$} \\
\hline $\mathrm{H}_{2}$ to $\mathrm{N}_{2}$ & 13.2 & 742.9 & 182.5 & 37.1 & 14.2 & 15.2 & $45-\infty$ & $350-\infty$ & $1072-\infty$ & $284-\infty$ & $254-\infty$ \\
\hline $\mathrm{H}_{2}$ to $\mathrm{CO}_{2}$ & 12.1 & 630.7 & 156.4 & 29.7 & 11.2 & 10.3 & $\infty$ & $\infty$ & $\infty$ & $\infty$ & $\infty$ \\
\hline $\begin{array}{l}\mathrm{H}_{2} \text { to } \mathrm{CO} \\
\text { Permeability, }\end{array}$ & 13.2 & 735.8 & 182.5 & 39.1 & 13.2 & 13.1 & $\infty$ & $\infty$ & $\infty$ & $\infty$ & $\infty$ \\
\hline $\mathrm{H}_{2}$ & 0.352 & 1.867 & 0.587 & 1.876 & 0.1716 & 0.135 & 1.940 & 1.656 & 1.456 & 2.392 & 1.932 \\
\hline $\mathrm{N}_{2}$ & 0.018 & 0.0016 & 0.0021 & 0.0446 & 0.0093 & 0.0073 & 0.034 & 0.0022 & 0.0014 & 0.0041 & 0.0037 \\
\hline $\mathrm{CO}_{2}$ & 0.019 & 0.0018 & 0.0024 & 0.0220 & 0.0110 & 0.0094 & & & & 0.0006 & 0.0032 \\
\hline $\mathrm{CO}^{2}$ & 0.018 & 0.0016 & 0.0020 & 0.0190 & 0.0093 & 0.0073 & & & & & \\
\hline
\end{tabular}

${ }^{a}$ Calculated from Eq. 1 in text where $\mathrm{H}_{2}$ is component $\mathrm{Y}$, and $\mathrm{X}$ is $\mathrm{N}_{2}, \mathrm{CO}_{2}$, or $\mathrm{CO}$. 
elsewhere. These membranes will be developed by using ceramic hot-gas particulate filters as a substrate on which to develop a thin-film membrane. After these membranes are developed and characterized, the two best membranes will be tested by mixing bottled gases in a manifold and feeding these gases to the membrane where gas composition and volumetric flow rates of the inlet, permeate, and raffinate gas streams will determine separation factors and permeabilities.

\subsection{REFERENCES}

1. Hackworth, J.H.; Mcllvried, H.G. "Evaluation of the Use of Membranes in Power Generation Systems Involving Coal Gasification," final report for contract no. DE-AC21-90MC27346; Nov. 1992, p 195.

2. Lin, C.L.; Wu, J.C.S.; Gallaher, G.R.; Smith, G.W.; Flowers, D.L.; Gerdes, T.E.; Liu P.K.T. "Gas Separations Using Ceramic Membranes," report for U.S. Department of Energy Contract No. DOE/MC/25135-3341 (DE93000278), Feb. 1993, p 191.

3. Wagner, C.D. et al. Handbook of X-Ray Photoelectron Spectroscopy; Perkin Elmer, 1979; p 56. 
M97005403

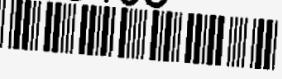

Report Number (14) DOE / nC/30097- 5674

subl. Date (11) 199508

sponsor Code (18) DOE/EE, XF

JC Category (19) $U C-101, D O E / E$

DOE 